\title{
CAPITAL MARKET SEBAGAI ALTERNATIF KEGIATAN EKSTRA KULIKULER DI SEKOLAH
}

\author{
Indriyana Widyastuti ${ }^{*}$, Saptani Rahayu ${ }^{2}$, Nugroho Wisnu Murti ${ }^{3}$ \\ STIE Adi Unggul Bhirawa Surakarta \\ *Email: indriyana_widy@yahoo.co.id
}

\begin{abstract}
ABSTRAK
Program Pengabdian kepada Masyarakat ini mengangkat tema memasyarakatkan budaya Investasi pada Instrumen Investasi jenis Pasar Saham. Urgensi pelaksanaan tersebut adalah fakta bahwa investasi pada saham belum menjadi pilihan favorit di Indonesia. Terkait dengan kondisi tersebut, Bursa Efek Indonesia (BEI) memiliki program khusus dengan perguruan tinggi dalam rangka meningkatkan ketertarikan terhadap investasi di pasar modal melalui media pendidikan. Kegiatan Pengabdian Kepada Masyarakat (PKM) untuk memenuhi kewajiban Tri Dharma Perguruan Tinggi Semester Genap 2018/2019. Secara konsisisten, tema PKM yang diselenggaran adalah Capital Market. Konsistensi tim PKM dalam menjadlankan tema ini berdasar kerja sama Perguruan Tinggi STIE AUB Surakarta dengan Bursa Efek Indonesia dalam bidang Pasar Modal baik dalam proses pendidikan, penelitian maupun pengabdian kepada masyarakat. Kegiatan PKM ini dilaksanakan di Sekolah Menengan Kejuruan Negeri 1 Surakarta, dengan peserta Guru Kelas SMK N 1 Surakarta sebanyak 21 orang, dan siswa sebanyak 4 orang. Kegiatan ini diselenggaran pada tanggal 9 Mei 2019 di Laboratorium Komputer, yang dilaksanakan dalam bentuk workshop dengan melibatkan semua peserta dalam praktek jual beli saham secara riil pada Pasar Modal Indonesia. Pada awal pelaksanaan PKM, peserta diminta mngerjakan soal dalam bentuk pihan ganda sebagai pre test. Tahap berikutnya dilakukan ceramah dan diskusi tentang Mekanisme dan Pengetahuan tentang Efek serta praktik real trading. Pelatihan ini diakhiri dengan laksanaan post test yang menjadi salah satau indokator efektifitas kegiatan PKM. Peningkatan pengetahuan peserta kegiatan rata-rata sebesar 48,89\% dan terbukti meningkat signifikan.Indikator capaikan kegiatan diukur dari nilai pretest dan post test oleh peserta kegiatan. Pre Test dan Post Test tersebut dilakukan secara online dengan link yang di bagikan kepada semua peserta kegiatan workshop. Nilai rata-rata pretest peserta adalah 5,85 dan meningkat menjadi 8.71 dapat sesi post test. Hasil tersebut memberikan penjelasan bahwa pengetahuan tentang pasar modal peserta yang menerima materi workshop yang disertai dengan praktik transaksi investasi saham meningkat sebesar 48,89\%. Peningkatan tersebut juga signifikan pada p-value $<0,01$. Tim PKM memberikan penghargaan kepada dua peserta dengan peningkatan nilai terbesar berupa rekening dana investasi (RDI) masing-masing senilai 100 ribu rupiah. Capaian ini menjadi awal untuk mendiskusikan rumusan kegiatan ekstrakulikuler di SMK N 1 Surakarta. Kesepakatan tersebut secara rinci akan dibahan kembali pada semester Gasal 2019/2020 yang membahas secara detail tentang rincian materi dan capaian pembelajaran pada peserta kegiatan ekstrakulikuler.
\end{abstract}

Kata Kunci : capital market, saham, workshop, investasi, ekstrakulikuler

\section{PENDAHULUAN}

Galeri Investasi BEI perguruan tinggi di Indonesia perlu lakukan ekspansi dan percepatan misi peningkatan aktivitas investasi tidak hanay gai mahasiswa saja, tetapi juga pelajar. Akan tetapi, proses intenalisasi tersebut memerlukan persamaan persepsi dengan guru sebagai tenaga pengajar siswa. Langkah tersebut mendasarkan pada fakta bahwa saaat ini persepsi terhadap investasi di pasar modal Indonesia memiliki resiko tinggi terhadap penipuan, isu judi termasuk mekanisme dan modal yang dibutuhkan adalah besar. Program pendidikan dalam rangka perceptan kegiatan investasi tersebut dapat ditunjukkan dari beberapa data sebagai berikut. Data Bursa Efek Indonesia (BEI) menunjukkan bahwa porsi kepemilikan domestik di pasar saham Indonesia meningkat cukup pesat. Kepemilikan domestik di pasar saham sebesar 37,08 persen diatahun 2013, sementara itu investor asing mendominasi sebanyak 62,94 persen. Akan tetapi, Pada tahun 2017 porsi kepemilikan asing di pasar saham sudah menyusut menjadi 52,23 persen. Meskipun data diatas menunjukan tren kenaikan, tetapi percepatan program BEI dalam memsyarakatkan pasar modal perlu ditingkatkan terutama dengan mitra Galeri Investasi BEI yang tersebar di beberapa perguruan tinggi di Indoensia. Salah satu factor yang diduga kuat mempengaruhi tren peningkatan kepemilikan investor domestic adalah deregulasi aturan perdagangan pasar saham yang 
dilakukan oleh BEI. Salah satunya adalah penurunan jumlah transaksaksi LOT saham yang semula 500 lembar per lot, menjadi 100 lembar per lot. Pengurangan ini sangat memungkiankan bahwa pembelian saham dalam jumlah minimal satu lot dapat terjangkau oleh lapisan ekonomi menengah bahkah menengah ke bawah. Hal tersebut juga diperkuat dengan adanya program BEI "Sahamku 100”. Program tersebut dibuka khususnya untuk pelajar dan mahasiswa yang dapat memulai berinvestasi dengan membuat akun investasi hanya dengan dana Rp. 100.000,-.

Galeri Investasi BEI yang dibentuk oleh BEI di beberapa perguruan tinggi Indonesia menjadi salah satu komitmen BEI dalam memasyarakatkan investasi di pasar modal melalui jalur pendidikan. Galeri Investasi Bursa Efek Indonesia (BEI) adalah sarana untuk memperkenalkan Pasar Modal sejak dini kepada dunia akademisi. Galeri Investasi BEI berkonsep 3 in 1 yang merupakan kerjasama antara BEI, Perguruan Tinggi dan Perusahaan Sekuritas diharapkan tidak hanya memperkenalkan Pasar Modal dari sisi teori saja akan tetapi juga prakteknya (PT Bursa Efek Indonesia, 2018). Lebih lanjut dijelaskan bahwa Galeri Investasi BEI yang menyedikan real time information untuk belajar menganalisa aktivitas perdagangan saham, diharapkan dapat menjadi jembatan menuju penguasaan ilmu pengetahuan beserta prakteknya di pasar modal.

Galeri Investasi BEI menyediakan semua publikasi dan bahan cetakan mengenai pasar modal yang diterbitkan oleh Bursa Efek Indonesia termasuk peraturan dan Undang-Undang Pasar Modal. Informasi dan data yang ada di Galeri Investasi BEI dapat digunakan oleh civitas akademika untuk tujuan akademik, bukan untuk tujuan komersial dalam hal transaksi jual dan beli saham. Galeri Investasi BEI diharapkan dapat saling memberikan manfaat bagi semua pihak sehingga penyebaran informasi pasar modal tepat sasaran serta dapat memberikan manfaat yang optimal bagi mahasiswa, praktisi ekonomi, investor, pengamat pasar modal maupun masyarakat umum di daerah dan sekitarnya baik untuk kepentingan sosialisasi dan pendidikan/edukasi pasar modal maupun untuk kepentingan ekonomis atau alternatif investasi.

Tugas dan fungsi GI BEI sebagaimana yang disampikan diatas adalah searah dengan tugas tri dharma perguruan tinggi utamanya pada program pengabdian kepada masyarakat. Dengan demikian, kegiatan pengabdian kepada masyarakat utamanya mengambil tema memberikan pengathuan tentang efek dipasar modal sejak dini kepada masyarakat Indonesia merupakan kewajiban GI BEI. Dukungan berupa media pembelajaran dipersiapkan atas kerja sama BEI dengan Galeri Investasi BEI dalam rangka memasyarakatkan investasi di pasar modal sejak dini. Media pembelajar tersebut antara lain: buku sekolah pasar modal, data historis harga saham dan instrument pasar modal yang lain, data laporan keuangan, data laporan keuangan yang ada pada web TICMI dan program sertifikasi Wakil Perantara Perdagangan Efek (WPPE). Media simulasi perdangan saham secara online juga dipersiapkan oleh BEI berupa akun virtual untuk belajar melakukan transaksi saham (IDX Virtual Trading).

Dengan demikian, kegiatan pengabdian ini dilaksanakan dalam bentuk inklusi pemahaman tentang perdagangan pasar modal di Indonesia dan simulasi perdagangan khususnya bagi guru. Tahap capaian atas kegiatan ini adalah 1) pemahaman guru terhadap pentingnya mengenal investaso di pasar modal sejak dini; 2) memahami transasksi real trading pasar saham Indonesia; 3) perumusan kegiatan ekstrakulikuler pasar modal untuk pelajar. Beberapa teknik analisis juga akan disampaikan dalam kegiatan ini baik fundamental maupun tehnikal. Hal tersebut mempertimbangkan penjelasan tentang analisis fundamental saham bahwa analisa fundmental akan memberikan keyakinan lebih pada keputusan jual beli ataupun investasi saham dalam jangka pendek yang sebelumnya diprediksi berdasarkan analisa teknikal (Desmond, 2011). Analisa Fundamental untuk memprediksi pergerakan harga saham diidentifikasi menjadi tiga bagian antara lain 1) analisa makro ekonomi; 2) analisa sektoral dan 3) analisa kinerja emiten (Desmond, 2011). Akan tetapi pelatihan focus pada Analisa fundamental makro ekonomi dan sectoral yang dijelaskan sebagai bahan pertimbangan yang seringkali digunakan 
untuk investasi saham jangka pendek (Murti \& Widyastuti, 2017). Informasi sectoral dan fundamental makro ekonomi ditunjukan dari informasi yang secara rutin tersedia dalam menu news pada aplikasi relitrade Next G dan aplikasi android RTI business.

Salah satu indikator yang dapat digunakan untuk melakukan analisis saham secara fundamental adalah Price Earning Ratio (PER). PER merupakan rasio yang membandingkan antara harga saham yang diperoleh dari pasar modal dengan laba per saham yang disajikan dalam laporan keuangan (Desmond, 2011: 77). Semakin tinggi rasio PER mengindikasikan bahwa kinerja perusahaan juga semakin membaik. Perhitungan Price earning ratio dapat melihat penghargaan pasar terhadap kinerja perusahaan dari indikator earning per share (EPS). Price earning ratio menunjukkan hubungan antara pasar saham biasa dengan earning per share. Angka rasio ini biasanya digunakan investor untuk memprediksi kemampuan perusahaan dalam menghasilkan laba dimasa yang akan datang.

Perusahaan yang mempunyai peluang tingkat pertumbuhan tinggi, pada umumnya memiliki price earning ratio yang tinggi, dan hal ini menunjukkan bahwa pasar mengharapkan pertumbuhan laba di masa mendatang. Di sisi lain, perusahaan dengan tingkat pertumbuhan yang rendah cenderung mempunyai price earning ratio yang rendah. Semakin rendah price earning ratio, semakin baik atau murah harganya untuk diinvestasikan. Price earning ratio menjadi rendah nilainya bisa karena harga saham cenderung semakin turun atau karena meningkatnya laba bersih perusahaan. Dengan demikian, semakin kecil nilai price earning ratio maka semakin murah saham tersebut untuk dibeli (Desmond, 2011: 78).

Earning per share merupakan salah satu indikator utama yang diperhatikan oleh investor untuk memutuskan investasi dengan harapan pengembalian yang tinggi dari investasinya. Investor akan lebih tertarik pada perusahaan yang memiliki earning per share yang tinggi (Desmond, 2011: 77). Penjelasan tersebut menggambarkan bahwa tinggi rendahnya earning per share suatu perusahaan akan berakibat pada harga pasar sahamnya di pasar saham. Penjelasan tersebut dibuktikan pada penelitian di sektor manufacture jenis consumer and goods (Setyaningsih, 2011). Namun demikian terdapat penelitian yang tidak dapat membuktikan pengaruh signifikan EPS terhadap Return Saham pada sektor farmasi (Risdiyanto, 2016). Penelitian pada sektor properti juga tidak dapat membuktikan pengaruh EPS terhadap return saham (Sinambela, 2011)

\section{METODE}

Rancangan kegiatan pengabdian kepada masyarakat untuk mencapai target dan luaran atas rumusan masalah yang disampaikan diatas dapat ditunjukkan pada Tabel 1. Outcome yang harapkan dalam jangka panjang atas capaian rangkain kegiatan yang ditunjukkan pada Tabel tersebut adalah pembentukan rekening investasi oleh pelajar.

Tabel 1 .Rancangan dan Bentuk Kegiatan

\begin{tabular}{|l|l|l|}
\hline Masalah & Solusi & Langkah kegiatan*) \\
\hline - Diperlukannya pendidikan & Pengenalan Pengetahuan tentang & Inklusi pendidikan Capital \\
capital market sejak dini & efek kepada pelajar SMA/SMK & Market kepada Guru \\
sebagai percepatan misi Bursa & melalui kegiatan ekstrakulikuler & sekolah sebagai langkah \\
Efek Indonesia untuk & secara terstruktur yang dimulai & awal merumsukan \\
meningkatkan kegiatan & dari Guru & pendidikan capital market \\
investasi di Pasar Modal & & dalam kurikulum ekstra di \\
Indonesia & & sekolah \\
\hline
\end{tabular}




\begin{tabular}{|c|c|c|}
\hline 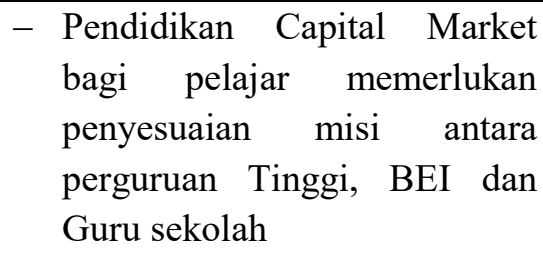 & & $\begin{array}{l}\text { Coaching investasi dan } \\
\text { trading saham untuk Guru }\end{array}$ \\
\hline $\begin{array}{l}\text { - Inklusi pendidikan Capital } \\
\text { Market di sekolah tidak hnya } \\
\text { membutuhkan pelatihan } \\
\text { incidental tetapi juga } \\
\text { pendampingan (coaching) }\end{array}$ & $\begin{array}{lrr}- & \text { Coaching investasi dan } \\
& \text { trading saham untuk Guru } \\
\text { - } & \text { Kesepakatan } & \text { untuk } \\
& \text { merumuskan } & \text { kegiatan } \\
& \text { ekstrakulikuler } & \text { pendidikan } \\
& \text { Capital Market } & \end{array}$ & $\begin{array}{lr}\text { Merumusakan } & \text { kegiatan } \\
\text { ekstrakulikuler } & \text { terstruktur } \\
\text { di sekolah } & \end{array}$ \\
\hline
\end{tabular}

*) Langkah kegiatan secara rinci dapat ditunjukkan pada Tabel 2.

Tabel 2. Rincian Langkah -Langkah Kegiatan

\begin{tabular}{|c|l|}
\hline No & Rincian Kegiatan \\
\hline 1 & Pre-test pengetahuan tentang efek \\
\hline 2 & Penyampaian materi Pengetahuan tentang efek \\
\hline 3 & Penyampaian materi Mekanisme perdagangan efek \\
\hline 4 & Diskusi \\
\hline 5 & Praktek real trading \\
\hline 6 & Post test \\
\hline 7 & $\begin{array}{l}\text { Diskusi pembahasan draft perumusan awal kurikulum ekstrakulikuler pendidikan Capital } \\
\text { Market }\end{array}$ \\
\hline
\end{tabular}

Beberapa hal yang saling terkait antara lembaga/instansi sebagai potensi tercapainya target dan tujuan kegiatan ini dapat dijelaskan pada Tabel 3.

Tabel 3. Pihak (Mitra) kegiatan dan peran

\begin{tabular}{|l|l|l|}
\hline No & Instansi & Peran \\
\hline 1 & Galeri Investasi (GI) BEI & $\begin{array}{l}\text { Mempersiapkan personil Rangkaian kegiatan PKM yang } \\
\text { terdiri dari: } \\
\text { STIE AUB Surakarta } \\
\text { 1. Instruktur Pasar Modal }{ }^{*} \text { ) } \\
\text { Tim Pencacah dalam membantu pelatihan stock lab game } \\
\text { dari Mahasiswa (Kelompok Studi Pasar Modal) }\end{array}$ \\
\hline 2 & P3M STIE AUB Surakarta & $\begin{array}{l}\text { Memberikan penugasan kepada tim pengusul kegiatan } \\
\text { Pengabdian Kepada Masyarakat (PKM) serta melakukan } \\
\text { monitoring dan evaluasi kegiatan }\end{array}$ \\
\hline 3 & $\begin{array}{l}\text { Bursa Efek Indonesia (BEI) } \\
\text { Cabang Surakarta }\end{array}$ & Memberikan bantuan pemateri dan subsidi pendanaan \\
\hline
\end{tabular}




\begin{tabular}{|l|l|l|}
\hline 4 & SMK Negeri 1 Surakarta & $\begin{array}{l}\text { Koordinasi dengan tim PKM atau GI BEI STIE AUB dalam } \\
\text { mempersiapkan jadwal kegiatan, tempat dan peserta kegiatan }\end{array}$ \\
\hline$\left.{ }^{*}\right)$ & \multicolumn{2}{|c|}{ Personil GI BEI sekaliguis tim PKM beserta tim pencacah lain terlampir dalam lampiran 1 }
\end{tabular}
(Curriculum Vitae)

\section{HASIL DAN PEMBAHASAN}

Kegiatan diikuti oleh 25 peserta yang terdiri dari 21 Guru kelas dan 4 Murid SMK N 1 Surakarta. Kegiatan workshop tersebut dilaksanakan tanggal 9 Mei 2019 di Laboratorium Komputer SMK N 1 Surakarta. Pelaksanaan workshop dimulai pukil 08.00 sampai dengan 12.00. Rincian kegiatan tersebut ditunjukkan pada Tabel 3.1. seluruh peserta mengerjakan soal pretest dan post test untuk mengukur salah satu indikator keberhasilan pelaksanaan PKM. Pretest dan post test dikerjakan secara online dengan aplikasi google form. Seluruh peserta dapat secara langsung mengetahui hasil test yang dikerjakan. Sementara itu, materi 2 dan 3 sebagaimana ditunjukkan pada Tabel 4 disampaikan dengan metode tutorial dengan materi yang dibagikan kepada seluruh peserta yang juga dapat diunduh secara online. Selama penyampaian materi tersebut, peserta dapat secara langsung memberikan tanggapan atau pertanyaan selama sesi materi. Daftar hadir peserta kegiatan ditunjukkan pada Lampiran 1.

\section{Tabel 4. Rincian dan durasi kegiatan PKM}

\begin{tabular}{|c|c|c|}
\hline No & Rincian Kegiatan & $\begin{array}{l}\text { Waktu yang } \\
\text { dibutuhkan }\end{array}$ \\
\hline 1 & Pre-test pengetahuan tentang efek & 15 menit \\
\hline 2 & Penyampaian materi Pengetahuan tentang efek dan diskusi & 40 menit \\
\hline 3 & Penyampaian materi Mekanisme perdagangan efek dan diskusi & 40 menit \\
\hline 4 & Praktek real trading & 90 menit \\
\hline 5 & Post test & 15 menit \\
\hline 6 & $\begin{array}{l}\text { Diskusi pembahasan draft perumusan kurikulum ekstrakulikuler pendidikan } \\
\text { Capital Market }\end{array}$ & 30 menit \\
\hline
\end{tabular}


Tabel 5. Indikator dan capaian kegiatan PKM

\begin{tabular}{|c|c|c|c|}
\hline No & Rincian Kegiatan & Indikator target capaian & Capaian \\
\hline 1 & $\begin{array}{l}\text { Pre-test pengetahuan tentang } \\
\text { efek }\end{array}$ & $\begin{array}{l}100 \% \text { soal pilihan ganda selesai } \\
\text { dikerjakan semua peserta }\end{array}$ & \\
\hline 2 & $\begin{array}{l}\text { Penyampaian materi } \\
\text { pengetahuan tentang efek }\end{array}$ & $\begin{array}{l}100 \% \text { materi Pengetahuan tentang efek } \\
\text { dan mekanisme perdagangan efek } \\
\text { tersampaikan kepada peserta }\end{array}$ & $100 \%$ \\
\hline 3 & $\begin{array}{l}\text { Penyampaian materi } \\
\text { mekanisme pedagangan efek }\end{array}$ & $\begin{array}{l}100 \% \text { materi Pengetahuan tentang efek } \\
\text { dan mekanisme perdagangan efek } \\
\text { tersampaikan kepada peserta }\end{array}$ & $100 \%$ \\
\hline 4 & Diskusi & $\begin{array}{l}\text { Minimal } 20 \% \text { peserta bertanya tentang } \\
\text { materi yang telah disampaikan }\end{array}$ & $\begin{array}{l}\text { Seluruh peserta } \\
\text { bertanya tentang } \\
\text { materi workshop }\end{array}$ \\
\hline 5 & Praktek real trading & $\begin{array}{l}\text { Seluruh peserta mengikuti praktek real } \\
\text { trading dan mampu melakukan belu dan } \\
\text { jual saham disertasi analisis dasar }\end{array}$ & $100 \%$ \\
\hline 6 & Post test & Rata - rata kenaikan minimal nilai $40 \%$ & $\begin{array}{l}\text { meningkat sebesar } \\
48.89 \%\end{array}$ \\
\hline 7 & $\begin{array}{lr}\text { Diskusi pembahasan draft } \\
\text { perumusan } & \text { kurikulum } \\
\text { ekstrakulikuler } & \text { pendidikan } \\
\text { Capital Market } & \end{array}$ & $\begin{array}{l}\text { Kesepakatan untuk melakukan tindak } \\
\text { lanjut perumusan } \\
\text { ekstrakulikuler capital market }\end{array}$ & $\begin{array}{l}\text { Dilaksanakan } \\
\text { pada semester } \\
\text { ganjil } 2019 / 2020\end{array}$ \\
\hline 8 & \begin{tabular}{|lrr} 
Publikasi & Ilmiah & Jurnal \\
Pengabdian & & Kepada \\
Masyarakat & & \\
\end{tabular} & Submit & Submit \\
\hline
\end{tabular}

Capaian kegiatan PKM ini diukur dengan beberapa indikator dan capaian yang ditunjukkan pada Tabel 5. Informasi penting yang perlu disampaikan pada capian kegiatan ini adalah nilai rata-rata pretest peserta adalah 5,85 dan meningkat menjadi 8,71 dapat sesi post test (meningkat sebesar 48.89\%).

Seluruh rangkaian kegiatan telah telah terlaksana sesuai dengan jadwal dan susuan kegiatan yang direncanakan. Indikator utama yaitu peningkatan pengetahuan peserta dapat tercapai sepenuhnya. Namun demikian, capaian kegiatan memerlukan tindak lanjut terutama diskusi tentang perumusakan kegiatan ekstrakulikuler yang akan diikuti oleh peserta siswa SMA. Perumusan materi tersebut akan dilaksankan pada semester Ganjil 2019/2020 


\section{Gambar Dokumentasi kegiatan}
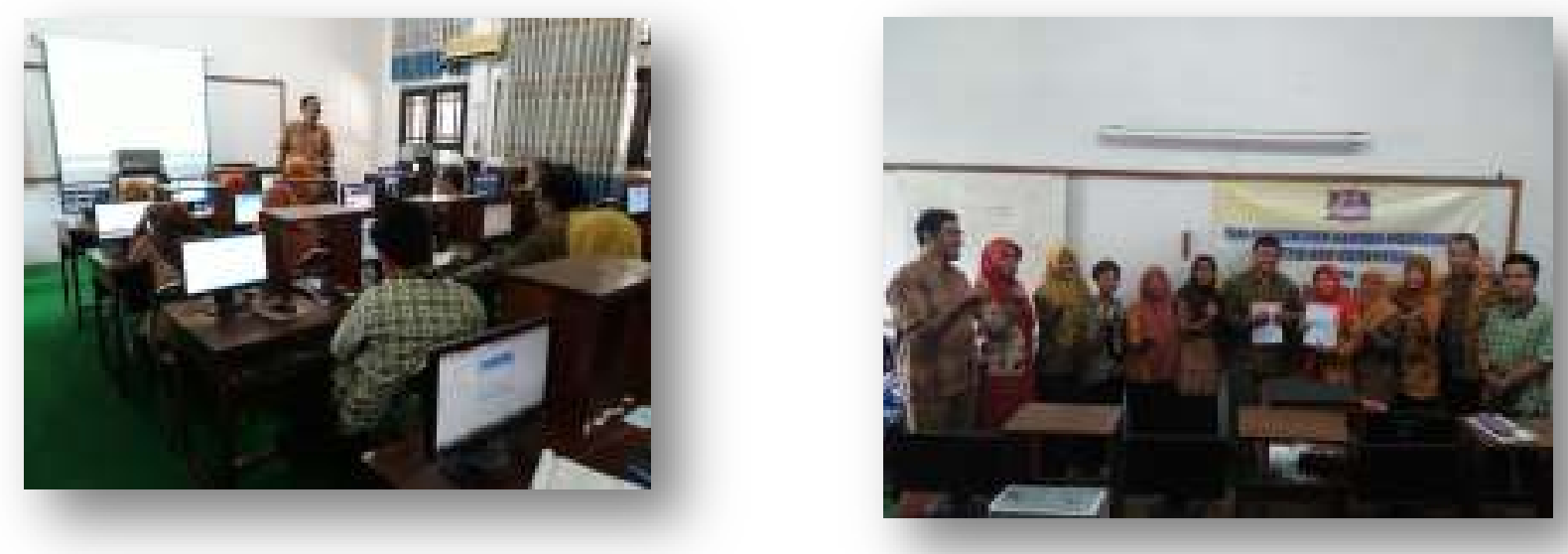

\section{KESIMPULAN}

Kegiatan PKM dengan tema workshop dan pendampingan praktik real trading saham pada Pasar Modal Indonesia telah selesai dilaksanakan yang diikuti oleh 21 Guru dan 4 siswa SMK N 1 Surakarta. Capaian kegiatan pengabdian kepada masyarakat yang terdiri dari 3 indikator utama antara lain 1). Peningkatan pengetahuan tentang efek mencapai $48.89 \% \%$ berdasar pre dan post test; 2) partisipasi peserta dalam workshop 3) Kesepakatan perumusakan kurikulum kegiayan ekstrakuliler yang akan dilakukan pada semester Ganjil 2019/2020. Uji statistic yang dilakukan juga menemukan bahwa terdapat peningkatan signifikan pada sebelum dan sesudah peserta mendapatkan ceramah dan simulasi tentang perdagangan efek di pasar modal Indonesia. Hasil tersebut memberikan indikasi bahwa kegiatan ceramah yang dilengkapi dengan praktik trading saham secara online dalam memahami sebuah proses atao prosedur tertentu. Kegiatan ini juga memberikan penghargaan kepada dua peserta workshop yang memperoleh nilai peningkatan tertinggai atas pre dan post test.

Kegiatan ini dibatasi dengan jumlah peserta untuk mencapai efektifitas proses pemberian pemahaman materi termasuk simulasi dengan peralatan dengan jumlah yang terbatas. Proses dengan batasan jumlah tersebut dapat direkomendasikan untuk mencapai efektifitas kegiatan PKM dengan bentuk sosialisasi, penyuluhan yang bersifat insedental. Namun demikian, capaian jumlah peserta dapat dilakukan dengan rangkaian kegiatan yang dapat dilakukan dalam beberapa waktu dan kelompok peserta yang terpisah. Hal tersebut dapat bermanfaat untuk memberikan data observasi yang lebih banyak untuk generalisisi efektifitas metode tertentu dalam berbagaimacam kegiatan PKM.

\section{DAFTAR PUSTAKA}

Desmond, W. (2011). Analisis Fundamental Saham (2nd ed.). Jakarta: Exceed.

Jogiyanto. (2012). Teori Portofolio dan Analisis Investasi (3rd ed.). Yogyakarta, Indonesia: BPFE Yogyakarta.

Khoroshilov, Y. (2013). Momentum trading strategy and investment horizon : an experimental study. Journal of Economic Stiudoes, Emerald Group Publishing Limited, 39(1), 4-12.

Murti, N. W., \& Widyastuti, I. (2017). Merumusakan Pertimbangan Keputusan Cut Gain dan Cut Loss Aktifitas Jual Beli Saham Bagi Tipe Swinger dan Scalper. In Prosiding Seminar Nasional \& Call for Paper: Hasil Penelitian dan pengabdian kepada masyarakat Universitas Muhammadiyah 
Semarang (pp. 380-198).

PT Bursa Efek Indonesia. (2018). Galeri Investasi BEI. Retrieved October 23, 2018, from http://www.idx.co.id/produk/galeri-investasi-bei/

Risdiyanto. (2016). Pengaruh ROI, EPS dan PER terhadap Return Saham pada Perusahaan Farmasi. Jurnal Ilmu Dan Riset Manajemen STESIA, 5(7), 1-15.

Setyaningsih, A. H. dan S. (2011). Pengaruh Economic Value Added, Market Share, Earnings Dan Net Cash Flow Terhadap Return Saham ( Studi Pada Perusahaan Manufaktur Jenis Consummer Goods Di Bursa. Jurnal Wora Ekonomi Mikrosil, STIE MIKROSIL, 1(2), 79-87.

Sinambela, E. (2011) Pengaruh Earning Per Share Terhadap Return Saham Pada Perusahaan Property dan Real Estate Yang Terdaftar di BEI 